\title{
Bacteriophage $\mathrm{T} 4$ ribonucleoside diphosphate reductase: on the defect causing decreased formation of the $\beta_{2}^{93}$ subunit encoded by the $n r d B 93$ mutant gene
}

(dNTP synthesis; multienzyme complex; gene expression; transcription; translation; protein degradation)

\author{
John M. Hilfinger and Ping He \\ Department of Biological Chemistry, The University of Michigan, Ann Arbor, MI 48109-0606, USA.
}

Received by J.P. Richardson: 8 June 1993; Revised/Accepted: 8 November/9 November 1993; Received at publishers: 24 January 1994

\section{SUMMARY}

Bacteriophage T4 ribonucleoside diphosphate reductase is composed of two proteins, $\alpha_{2}$ and $\beta_{2}$, encoded by the $n r d A$ and $n r d B$ genes, respectively. The expression of $n r d B$ is the limiting factor for the assembly of the enzyme. A recently described mutation, $n r d B 93$, may give new insight into the regulation of synthesis of the $\beta$ subunit encoded by $n r d B$. Infection by $\mathrm{T} 4 \mathrm{nrdB} 93$ produced only low concentrations of the $\beta_{2}^{93}$ protein. However, a site-specific mutation of phage T4 gene 39, encoding one of the subunits of T4 DNA topoisomerase, phenotypically suppressed the defect. The present work sought to characterize the nature of this defect. The mutation in $\operatorname{nrdB} 93$ was a single-base transition $(\mathrm{G} \rightarrow \mathrm{A})$ resulting in a Gly ${ }^{253} \rightarrow$ Asp change. In vivo and in vitro studies provided no evidence of degradation of the $\beta_{2}^{93}$ protein. Furthermore, the decrease in $\beta_{2}^{93}$ formation was not caused by a delayed onset of transcription, neither by a decreased rate of mRNA formation from the $n r d B$ promoter, nor by a defective intron splicing of the $n r d B$ gene or in the transcription of the terminal segments of the message. These findings are consistent with the concept that the $\operatorname{nrdB93}$ lesion produces a defect at the level of translation.

\section{INTRODUCTION}

Bacteriophage -T4-encoded ribonucleoside diphosphate reductase is required in the assembly of the dNTP synthetase complex (Chiu et al., 1982; Moen et al., 1988) and appears to be the last factor in place and the keystone in the asscmbly of the complex (Greenberg et al., 1994). The $\alpha$ and $\beta$ chains of this $\alpha_{2} \beta_{2}$ enzyme are encoded by the T4 nrdA gene and the intron-containing $\operatorname{rrdB}$ gene, respectively (Yeh and Tessman, 1969; Yeh et al., 1972;

Correspondence to: Dr. J.M. Hilfinger at his present address: Department of Internal Medicine, MSRB I, University of Michigan, Ann Arbor, MI 48109-0680, USA, Tel. (1-313) 763-5090; Fax (1-313) 763-4151.

Abbreviations: aa, amino acid(s); bp, base pair(s); Cm, chloramphenicol; $\operatorname{den} A, \mathrm{~T} 4$ gene encoding endonuclease $\mathrm{A} ; \mathrm{dNTP}$, deoxyribonucleoside triphosphate; $f r d$, T4 gene encoding dihydrofolate reductase; $g y r B$, host
Tseng et al., 1988; 1990). The synthesis of the $\beta_{2}$ subunit is initiated after the synthesis of $\alpha_{2}$ protein begins (Tomich et al., 1974; Chiu et al., 1976; 1982; E.M. Kutter, personal communication to G.R. Greenberg).

Phage T4 $n r d B 93$, a temperature-sensitive mutant (Cook et al., 1988; Wirak et al., 1988) provides a tool to study the regulation of $\beta_{2}$ synthesis. This mutant was isolated from $t s \mathrm{G} 41$, a T4 DNA delay mutant originally thought to contain a single mutation in gene 39 (Epstein et al., 1963), encoding the ATPase subunit of T4 DNA

gene encoding one of the gyrase subunits; kb, kilobase(s) or $1000 \mathrm{bp}$; mot $A$, T4 gene encoding protein modifier of transcription; NADH, reduced nicotinamide-adenine dinucleotide; $n r d B$, $\mathrm{T} 4$ gene encoding ribonucleoside diphosphate reductase $\beta_{2}$ subunit; $n r d B 93$, T4 mutant gene encoding the ribonucleoside diphosphate reductase $\beta_{2}^{93}$ subunit; nt, nucleotide(s); oligo, oligodeoxyribonucleotide; $P_{\text {nrdB }}$, promoter located immediately upstream from the $n r d B$ gene; SDS, sodium dodecyl sulfate; wt, wild type. 
topoisomerase (Huang, 1986). Wirak and co-workers (1988) found that the $t s \mathrm{G} 41$ mutant actually harbored two mutations, $n r d B 93$ in the $\operatorname{nrdB}$ gene and 39-01 in gene 39. Phage T4 39-01 shows a slight delay in DNA synthesis at either $30^{\circ}$ or $41^{\circ} \mathrm{C}$. However, phage T4 $n r d B 93$ grows very poorly at any temperature. The infection with the T4 double mutant is temperature-sensitive and results only in the typical delay in DNA replication.

The $n r d B 93$ mutation produces two very different phenotypes. (i) $\beta_{2}^{93}$ activity is much more labile than $\beta_{2}$ activity, even at permissive temperatures. (ii) The level of $\beta^{93}$ chain synthesis varies from zero to about $10 \%$ of wt, even at $30^{\circ} \mathrm{C}$, the permissive temperature employed. This defective synthesis is phenotypically suppressed by the second mutation, 39-01. In addition, the suppression requires the expression of the host $g y r B$ gene, encoding the corresponding ATPase subunit of DNA gyrase (DNA topoisomerase II) (Wirak et al., 1988; for a review of the system, see Greenberg et al., 1994). To better understand the nature of these interactions, we sought to determine the location of the $n r d B 93$ mutation and to characterize its physiological defect.

\section{EXPERIMENTAL AND DISCUSSION}

\section{(a) Site of the $n r d B 93$ mutation}

Using the dideoxynucleotide chain-termination RNA sequencing technique (Tseng et al., 1990; Zimmern and Kaesberg, 1978), we examined the entire coding sequences, the exon-intron junctions, as well as the upstream and downstream regions of the mature $n r d B$ and $n r d B 93 \mathrm{mRNAs}$ isolated after infection by phage T4D and the double mutant, 39-01 $n r d B 93$, respectively
(Wirak et al., 1988; Cook et al., 1988). A restriction map of the $n r d B$ gene and the sequencing strategy used to identify the $n r d B 93$ mutation is presented in Fig. 1. $n r d B 93$ was found to be a $C^{758} \rightarrow T$ transition $(G \rightarrow A$ in the mRNA) leading to a Gly ${ }^{253} \rightarrow$ Asp substitution (Fig. 2). The $\beta^{93}$ mutant subunit moves slightly more slowly than the wt $\beta$ chain in SDS-polyacrylamide gels (Cook et al., 1988; Tseng et al., 1992). No other mutations were found in this gene. In further support for the presence of only a single mutation, a $n r d B 93$ clone constructed by site-directed mutagenesis of the cloned $\operatorname{nrdB}$ gene produced the $\beta_{2}^{93}$ protein exhibiting the same enzymatic and physical behavior as that generated after infection by phage T4 39-01 nrdB93 (Tseng et al., 1992).

When $n r d B 93$ was discovered as a second mutation present in the gene $39 \mathrm{ts}$ G41 mutant, the two functions were suspected of being associated (Wirak et al., 1988), though the original search employed a mutagen (Epstein et al., 1963). The direction of the transitional mutation in $n r d B 93$ fits with the use of 5-bromodeoxyuridine mutagenesis $(\mathrm{C} \rightarrow \mathrm{T})$ in the isolation of the original ts $\mathrm{G} 41$ mutant. T4 nrdB93 grows very poorly whereas T4 39-01 shows wt growth, with only a slight delay in the initiation of T4 DNA replication. Therefore, we reasoned that $n r d B 93$ was the initial lesion and that 39-01 had been selected as a suppressor of the $\operatorname{nrdB93}$ defect.

\section{(b) Comparison of transcriptional activities of $n r d B$ and nrdB93}

The low level of $\beta_{2}^{93}$ protein that accumulates during infection with T4 $n r d B 93$ phage (Cook et al., 1988) might be explained by a decreased transcriptional activity. Recent work from this laboratory showed that transcription of the $n r d B$ gene initiates from a mot $A$-dependent

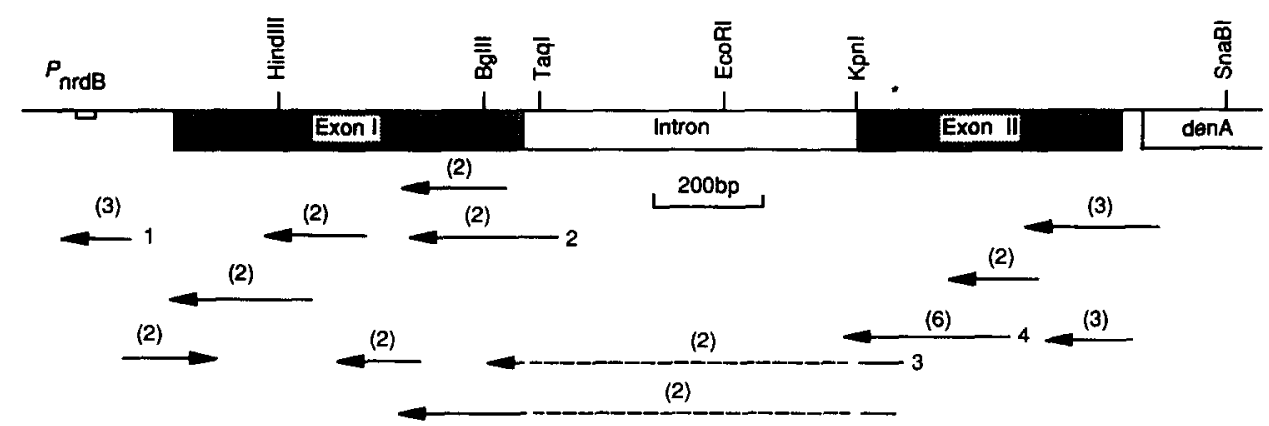

Fig. 1. The $n r d B$ gene region of phage T4 genome and the strategy employed in the search for the $n r d B 93$ mutation. The DNA segment shows the untranslated region between $n r d A$ and $n r d B$, the entire coding and intron portions of $n r d B$, and the $5^{\prime}$ coding frame of the denA gene. Also shown is the location of the mot $A$-dependent $n r d B$ promoter (Tseng et al., 1990). The arrows running from right to left represent the sequences determined with reverse transcriptase by extension of the $n r d B$ mRNA and a series of complementary oligo primers. The figures in parentheses over the arrows are the number of separate sequence analyses. The thick arrow, pointing from left to right, was a sequence analysis by the traditional Sanger method. The dotted lines represent the primer extensions through the intron splice junction, i.e., the mature mRNA. The approximate location of the $n r d B 93$ mutation is marked by an asterisk $\left(^{*}\right)$. The four arrows numbered at their end represent complementary oligo primers at particular sites in the gene and are mentioned in section $\mathbf{b}$ and the legends of Figs. 2 and 3. Transcription is rightward. Methods: RNA formed after T4 infection, primer extension and RNA sequencing were carried out as described (Tseng et al., 1990). Analysis of each nrdB93 mRNA sequence was carried out simultaneously with a wt mRNA control and was compared to known wt sequence. 
A.
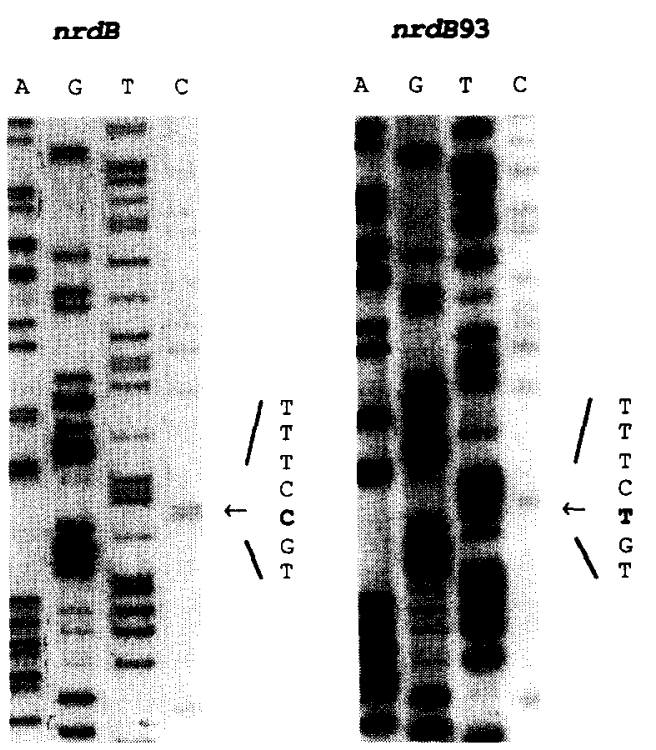

B.

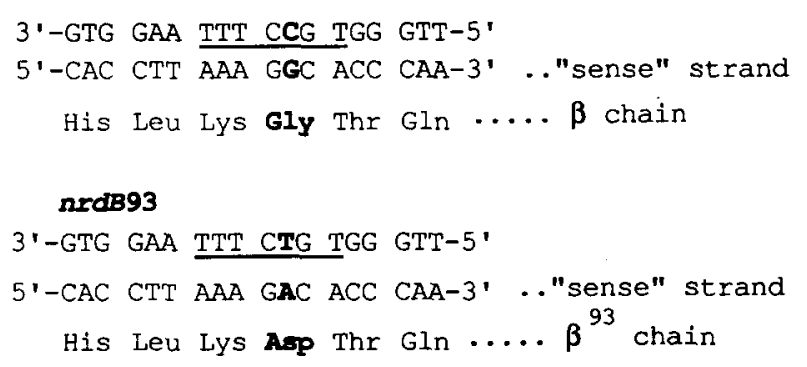

Fig. 2. Site of $n r d B 93$ mutation. (A) The arrows show the appearance in the reverse transcript of the $n r d B 93 \mathrm{mRNA}$ of a new thymine dideoxyribonucleotide termination band, replacing $\mathrm{C}^{758}$ in $n r d B$, at $94 \mathrm{nt}$ downstream from the intron junction. RNA sequencing was performed using primer 4 . (B) The underlined $n r d B$ sequence corresponds to the sequences under $\mathbf{A}$. The mutation corresponds to a Gly ${ }^{253} \rightarrow$ Asp substitution.

promoter, $P_{\mathrm{nrdB}}, 2-2.5 \mathrm{~min}$ after infection at $30^{\circ} \mathrm{C}$ (Tseng et al., 1990). Primer extension analysis and RNA sequencing by a reverse transcriptase using primer 1 (Fig. 1) were employed to determine the kinetics of formation and the sequence of the $5^{\prime}$ end of the mRNA encoding $n r d B 93$. In Fig. 3, we demonstrate that the $n r d B 93$ mRNA initiated from $P_{\text {nrdB }}$ was detectable at approx. 2 min after infection and quickly attained its highest level which was maintained throughout the time-course of the experiment. In addition, sequencing of the mRNA isolated at $8 \mathrm{~min}$ after infection demonstrates that the transcript is initiated at the same nt as the transcript synthesized during wt infection (Tseng et al., 1992).

During wt infection, transcripts initiating from $P_{\text {nrdB }}$ extend through the entire $n r d B$ gene and continue on through the den $A$ gene and gene 63 (Mileham et al., 1980; Sjöberg et al., 1986; Tseng et al., 1992). Since the lesion in the $n r d B 93$ gene might cause premature termination

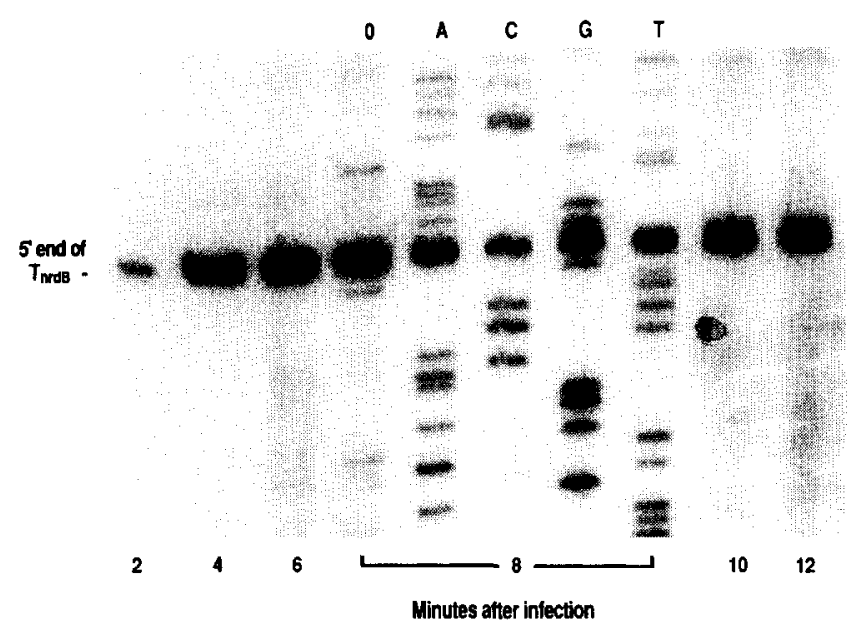

Fig. 3. Formation of the $5^{\prime}$ ends of the $n r d B$ and $n r d B 93$ transcripts. $40 \mu \mathrm{g}$ of total RNA prepared at 2, 4, 6, 8, 10 and 12 min after infection by $\mathrm{T} 4 \mathrm{nrdB} 93$ at $30^{\circ} \mathrm{C}$ were subjected to primer extension analysis using primer 1 (see Fig. 1) located $75 \mathrm{nt}$ from the $5^{\prime}$ end of the transcript. $T_{\text {nrdB }}$ is the transcript initiating from the $P_{\text {nrdB }}$ promoter (Tseng et al, 1990). In addition, the RNA taken at $8 \mathrm{~min}$ was sequenced with reverse transcriptase. Those sequences initiating upstream from $P_{\text {nrdB }}$ are from promoter, $P_{\mathrm{U}}$ (Tseng et al., 1988; 1990) positioned upstream from the frd gene, about $6 \mathrm{~kb}$ upstream from the $n r d B$ gene. Methods: RNA isolation, primer extension analysis and RNA sequencing were performed as described in the legend to Fig. 1.

of transcription of the mutant gene, the relative levels of the mRNA upstream and downstream from the mutation site were measured by dot blot hybridization of the RNA prepared at 2.5, 5, 8, 11 and 14 min after infection by $n r d B$ and $n r d B 93$ phage to radiolabeled DNA probes complementary to the two regions (Fig. 4). After infection with either $n r d B$ or $n r d B 93$ phage, the mRNA segments corresponding to the two regions were formed with virtually identical kinetics, indicating no premature termination. Furthermore, the sequence of the intron splice junction, GCGUGUAC, determined by RNA sequencing using primer 3 , was the same in mRNA isolated after phage $n r d B 93,39-01 n r d B 93$, and T4D infections (data not shown). Also, the sequence of the 5 '-terminal segment of the intron, determined by RNA sequencing using primer 2 complementary to a sequence $75 \mathrm{nt}$ inside the intron region (see Fig. 1), showed that the spliced $5^{\prime}$ end of the intron coincided exactly with that of wt (data not shown). These results argue strongly that the transcription of the $n r d B 93$ gene and post-transcriptional processing of the nrdB93 mRNA are not limiting the synthesis of $\beta^{93}$ protein chain.

\section{(c) Stability of $\beta_{2}^{93}$ protein}

One explanation for the low levels of the $\beta^{93}$ chain after infection by T4 $n r d B 93$ might be the rapid degradation of the $\beta_{2}^{93}$ protein. To examine its metabolic turnover, the proteins of $\mathrm{T} 4 \mathrm{nrdB}$ 93-infected cells were labeled with $\left[{ }^{35} \mathrm{~S}_{\mathrm{Na}_{2}} \mathrm{SO}_{4}\right.$ (Cook and Seasholtz, 1982). To prevent 


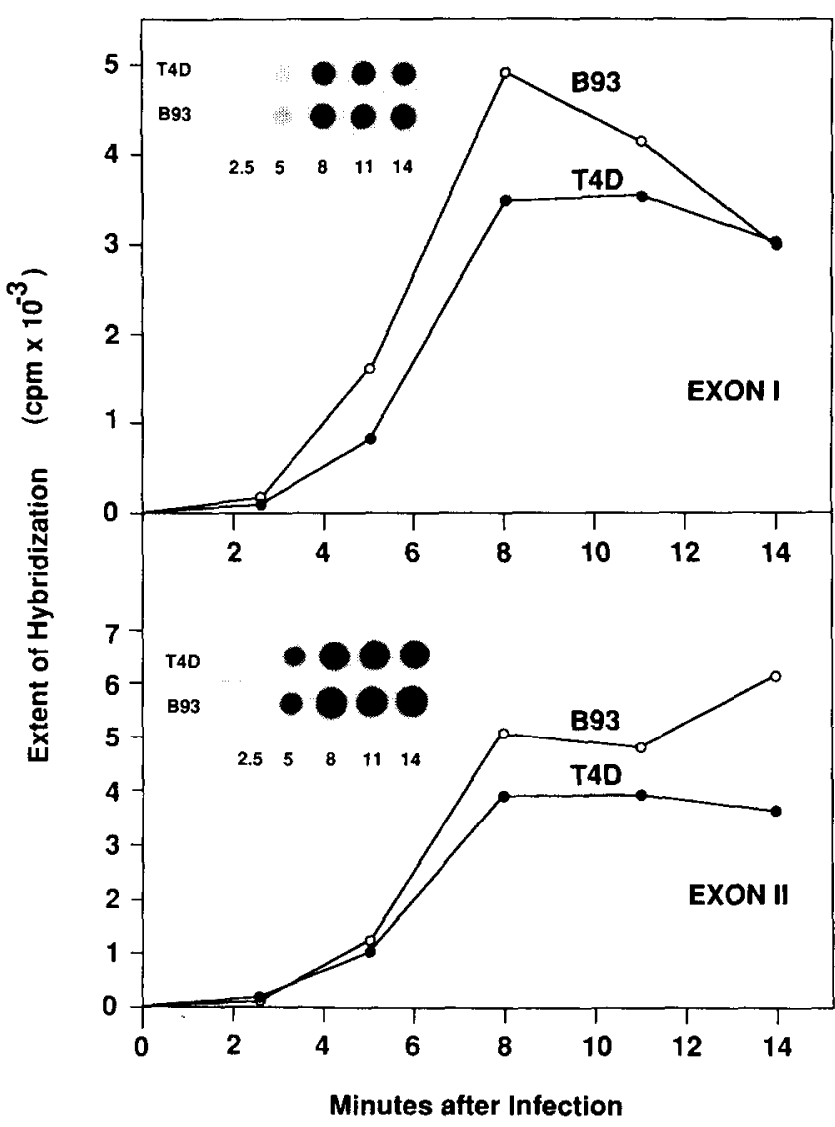

Fig. 4. Dot blot hybridization analysis of RNA prepared after infection with T4 $n r d B 93$ and T4D, using exon I and exon II fragments as probes. Aliquots $(5 \mu \mathrm{g})$ of total RNA prepared at various times after infection were subjected to dot blot hybridization using DNA probes derived from exon I or exon II fragments. The probe for exon I mRNA was the HindIII-BglII fragment and the probe for exon II mRNA was the $K p n I-S n a$ B1 fragment (see Fig. 1). Radioactivity in the hybridized fraction was determined with a Betagen Betascope 603 blot analyzer. An autoradiogram of the hybridization is shown in the upper left corner of each graph. The exposure time for the exon I autoradiogram was approx. $10 \mathrm{~h}$ and for the exon II autoradiogram about $36 \mathrm{~h}$. Methods: RNA was prepared from cells infected at $30^{\circ} \mathrm{C}$, as previously described (Tseng et al., 1990). DNA probes were labeled by the random primer labeling technique according to the manufacturer's specifications (Amersham, Arlington Heights, Il, IJSA). Hybridization was carried out with $5 \times 10^{6} \mathrm{cpm}$ of each DNA probe at a specific activity of $1 \times 10^{8}$ $\mathrm{cpm} / \mu \mathrm{g}$ of DNA using published procedures (Sambrook et al., 1989). The extent of hybrization was directly related to the amount of RNA used in the hybridization over a range from 1 to $10 \mu \mathrm{g}$ of RNA (data not shown).

further protein synthesis, $\mathrm{Cm}$ was added at $8.5 \mathrm{~min}$ after infection. Aliquots of infected cells were removed at various times afterward, and the proteins were subjected to two-dimensional gel electrophoretic analysis followed by autoradiographic exposure of the resulting gels for five or more days (Fig. 5). Because in the absence of the specific suppressor mutation of gene 39 the concentration of the $\beta^{93}$ chain was so low, only minimal radioactivity signals corresponding to the $\beta^{93}$ chain were detected at its position on the two-dimensional gel. However, direct measurement of radioactivity in the spots by scintillation spectrophotometry showed no decrease in concentration of the $\beta^{93}$ chain after $\mathrm{Cm}$ addition. To determine whether the $\beta_{2}^{93}$ protein was more prone than $\beta_{2}$ to degradation in vitro, purified proteins were incubated for up to $1 \mathrm{~h}$ at $37^{\circ} \mathrm{C}$ with the $30000 \times g$ supernatants of extracts prepared from sonicates of T4-infected cells. No increased degradation as compared to the wt protein was observed (not shown). Crude membrane preparations, characterized by their NADH oxidase activity, an enzyme found only in the cytoplasmic membrane of $E$. coli, also caused no degradation (data not presented). Since after infection with 39-01 $n r d B 93$ the $\beta^{93}$ chain is found at wt levels, it could be argued that gene 39 protein is a protease. However, purified gene 39 protein had no effect on the integrity of $\beta_{2}^{93}$ protein (data not shown). Taken together, these results rule out the possibility that the low level of $\beta_{2}^{93}$ found upon $n r d B 93$ infection is caused by an increased degradation of the mutationally altered subunit.

These studies demonstrate that the $n r d B 93$ defect is not at the transcription nor the intron-splicing steps, nor is it a result of increased degradation of the mutant protein chain.

To better understand the nature of the $n r d B 93$ defect, it is necessary to recount the factors involved in the expression of T4 $n r d B 93$ during infection. Table I shows the relative levels of the $\beta_{2}^{93}$ or $\beta_{2}$ protein after infection of $E$. coli with the following phage; $\operatorname{nrdB93}$, a gene 39 mutant, the double mutant, $39^{-}$nrdB93, or wt (Wirak et al., 1980; 1988; Wirak, 1981; Cook et al., 1988; G.R. Greenberg, personal communication). Infection with T4

\section{TABLE I}

Effect of temperature on formation of $\beta_{2}$ and $\beta_{2}^{93}$ proteins after infection with wt phage $\mathrm{T} 4$ and its mutants

\begin{tabular}{|c|c|c|}
\hline Phage $^{a}$ & $\begin{array}{l}\text { Temperature } \\
\left.\text { ( }{ }^{b} \mathrm{C}\right)\end{array}$ & $\begin{array}{l}\beta_{2} \text { or } \beta_{2}^{93} \\
\text { level }^{\mathrm{c}}\end{array}$ \\
\hline $39^{+} n r d B^{+}(w t)$ & $30 / 41$ & +++ \\
\hline $39-01 n r d B^{+}$ & $30 / 41$ & $+++d$ \\
\hline $39^{+} n r d B 93$ & 30 & $+1-$ \\
\hline $39^{+} n r d B 93$ & 41 & $+1-$ \\
\hline 39-01 nrdB93 & 30 & $+++d$ \\
\hline 39-01 nrdB93 & 41 & $+++d$ \\
\hline 39-01 nrdB93 (host gyrB) & 30 & $+1-$ \\
\hline
\end{tabular}

a Phages are described elsewhere (Cook et al., 1988; Wirak et al., 1988). The host gyrB mutant is himB104 (Wirak et al., 1988).

b $30 / 41$ means at either temperature.

${ }^{\mathrm{c}}$ Relative levels of $\beta_{2}$ or $\beta_{2}^{93}$ protein formed after infection of $E$. coli by the T4 phages $n r d B^{+}$(wt), nrdB93, 39-01 and the double mutant 39-01 $\operatorname{nrdB93}$, as measured by two-dimensional electrophoresis. $+/-$ indicates slight synthesis. $+++d$ indicates a delay of a few min in $\beta_{2}$ and $\beta_{2}^{93}$ protein formation upon infection by phage 39-01 as compared to $\beta_{2}$ protein formation upon wt T4 phage infection (Wirak et al., 1980), based on the tritium release assay (Tomich et al., 1974). 

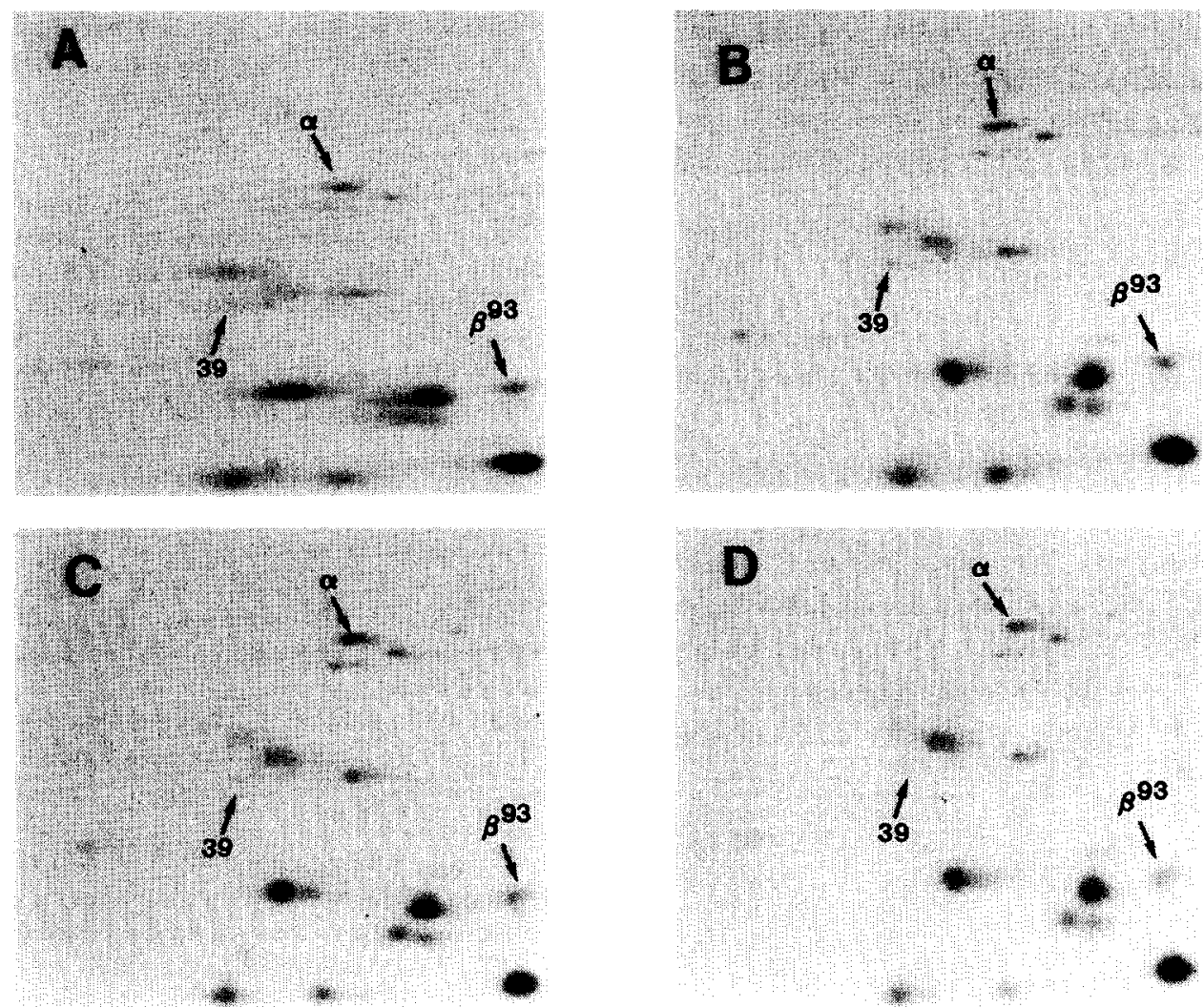

Fig. 5. $\beta_{2}^{93}$ stability in vivo; isotope turnover experiments. Two-dimensional electrophoretic gel patterns of ${ }^{35} \mathrm{~S}$-labeled proteins synthesized after T4 $n r d B 93$ infection at $30^{\circ} \mathrm{C}$. $\left[{ }^{35} \mathrm{~S}_{\mathrm{Na}_{2}} \mathrm{SO}_{4}\right.$ was added to $\mathrm{T} 4 \mathrm{nrdB} 93$-infected cells $3.5 \mathrm{~min}$ after infection. Protein synthesis was stopped at 8.5 min by addition of $\mathrm{Cm}$ to a final concentration of $100 \mu \mathrm{g} / \mathrm{ml}$. $2-\mathrm{ml}$ aliquots, equivalent to $1 \times 10^{9}$ infected cells, were removed at (A) $8.5 \mathrm{~min},(\mathbf{B}) 12.5 \mathrm{~min}$, (C) $16.5 \mathrm{~min}$ and (D) $25 \mathrm{~min}$ after infection. Samples equivalent to $2 \times 10^{8}$ infected cells were analyzed on each two-dimensional gel. The arrows point to the indicated $\alpha, \beta^{93}$ and gene 39 proteins. Methods: Infection of $E$. coli B with bactcriophage T4 was performed as described in earlier papers (Tomich et al., 1974; Tseng et al., 1988). Isotopic labeling of phage-encoded proteins with $\left[{ }^{35} \mathrm{~S}\right] \mathrm{SO}_{4}^{2-}$ (New England Nuclear) essentially followed the method described previously (Cook et al., 1982; 1988). Two-dimensional, nonequilibrium, pH-gradient electrophoresis was carried out as described earlier (Cook et al., 1982), except that the infected cells were extracted directly with SDS to prevent possible degradation (Burre et al., 1983).

$39^{+} n r d B 93$ at $30^{\circ} \mathrm{C}$ results in a very low level of $\beta^{93}$ chain in the cell. By contrast, infection with the T4 39-01 $n r d B 93$ double mutant results in a synthesis of its $\beta_{2}^{93}$ protein equivalent to that of wt infection. However, upon infection by the double mutant at $41^{\circ} \mathrm{C}$, the $\beta_{2}^{93}$ is both inactivated and unable to bind to the $\alpha_{2}$ subunit to yield the active $\alpha_{2} \beta_{2}$ enzyme complex, even though the $\beta^{93}$ chain is formed at wt levels (Cook et al., 1983; 1988). A temperature-insensitive suppression of the synthetic defect of $n r d B 93$ occurs by the site-specific mutation in gene 39 or by an amber mutation (amN116) in gene 39 (Wirak et al., 1988), but not by tsA41, a mutation at another site in the genc. This suppression is specific to the gene 39-encoded protein and does not involve T4 DNA topoisomerase activity (Cook et al., 1988).

These data suggest that translation of wt $n r d B$ mRNA is regulated in a positive fashion by the $n r d B$ gene product and in a negative manner by the gene 39 product. Thus, during $n r d B 93$ infection, wt levels of the mutant protein can be formed only when gene 39 is either site-specifically mutated or absent. In addition, Table I shows that the host $\operatorname{gyr} B$ gene is an integral part of this system, since little $\operatorname{nrdB} 93$ protein synthesis is seen in the absence of an active host $g y r B$ gene product. The concept of a translational mechanism controlling the $n r d B$ expression is strengthened by recent findings that the proteins encoded by gene $39, n r d B$ (and $n r d B 93$ ) and the host $g y r B$ gene have been shown to play roles in regulating the binding of the E. coli $30 \mathrm{~S}$ ribosome/tRNAs $\mathrm{s}_{\mathrm{f}}^{\text {Met }}$ complex by the ribosome-binding region (see McCarthy and Gualerzi, 1990) of T4 $n r d B$ mRNA through their specific interactions with the mRNA (P. He and G.R. Greenberg, data not shown).

\section{(d) Conclusions}

(1) The nrdB93 defect is a single nt change, from $\mathrm{G}^{758} \rightarrow \mathrm{A}$, leading to the Gly ${ }^{253} \rightarrow$ Asp change.

(2) The $\operatorname{nrdB} 93$ defect is not caused by a defect in transcription, post-transcriptional processing of $n r d B 93$ mRNA, or an increased degradation of $\beta_{2}{ }^{93}$. The data presented in this report are consistent with the concept that the defect is at the level of translation. 
(3) These results and previous findings (Cook et al., 1988; Wirak et al., 1988) provide strong argument that the products of the T4 $n r d B$ and 39 genes and the host gyrB gene have roles in the control of the $\operatorname{nrdB}$ translation.

\section{ACKNOWLEDGEMENTS}

These studies were supported in part by Public Health Service grant GM29025 from the National Institutes of Health to G.R. Greenberg. We would like to thank Dr. M.-J. Tseng for preparation of the plasmids used to generate DNA probes for this study. A generous gift of a series of oligos covering the T4 $n r d B$ gene was provided by Prof. Britt-Marie Sjöberg, University of Stockholm (Stockholm, Sweden).

\section{REFERENCES}

Burre, R.L., Formosa, T., Cook, K.S., Seasholtz, A.F., Hosoda, J. and Moise, H.: Use of two dimensional polyacrylamide gels to identify T4 prereplication proteins. In: Mathews, C.K., Kutter, E.M., Mosig, G., and Berget, P.B. (Eds.), Bacteriophage T4. American Society for Microbiology. Washington, DC, 1983, pp. 321-326.

Chiu, C-S., Cook, K.S. and Greenberg, G.R.: Characteristics of a bacteriophage T4-induced complex synthesizing deoxyribonucleotides. J. Biol. Chem. 257 (1982) 15087-15097.

Chiu, C.-S., Tomich, P.K. and Greenberg, G.R.: Simultaneous initiation of synthesis of bacteriophage T4 DNA and of deoxyribonucleotides. Proc. Natl. Acad. Sci. USA 73 (1976) 757-761.

Cook, K.S. and Greenberg, G.R.: Properties of bacteriophage T4 ribonucleotide diphosphate reductase subunits coded by $n r d A$ and $n r d B$ mutants. J. Biol. Chem. 258 (1983) 6064-6072.

Cook, K.S. and Seasholtz, A.F.: Identification of some bacteriophage T4 prereplicative proteins on two-dimensional gel patterns. J. Virol. 42 (1982) 767-772.

Cook, K.S., Wirak, D.O., Seasholtz, A.F. and Greenberg, G.R.: Effect of bacteriophage T4 DNA topoiomerase gene 39 on level of $\beta$ chain of ribonucleotide diphosphate reductase in a $\mathrm{T} 4 \mathrm{nrdB}$ mutant. J. Biol. Chem. 263 (1988) 6202-6208.

Epstein, R.H., Bolle, A., Steinberg, C., Kellenberger, E., Boy de la Tour, E., Chevalley, R., Edgar, R., Susman, M., Denhardt, G.H. and Lielausis, I.: Physiological studies of conditional lethal mutants of bacteriophage T4D. Cold Spring Harbor Symp. Quant. Biol. 28 (1963) 375-392.

Greenberg, G.R., He, P., Hilfinger, J.M. and Tseng, M.-J.: Deoxyribonucleoside triphosphate synthesis and phage T4 DNA replication. In: Karam, J.D. (Ed.), Bacteriophage T4 II, American Society for Microbiology, Washington, DC, 1994, in press.

Huang, W.M.: Nucleotide sequences of a type II DNA topoisomerase gene: Bacteriophage T4 gene 39. Nucleic Acids Res. 14 (1986) 7751-7765.

McCarthy, J.E.G. and Gualerzi, C.: Translational control of prokaryotic gene expression. Trends Genet. 6 (1990) 78-85.

Mileham, A.J., Revel, H.R. and Murray, N.E.: Molecular cloning of the T4 genome; organization and expression of the frd-DNA ligase region. Mol. Gen. Genet. 179 (1980) 227-239.

Moen, L.K., Howell, M.L., Lasser, G.W. and Mathews, C.K.: T4 phage deoxyribonucleoside triphosphate synthetase. J. Mol. Recog. 1 (1988) 48-57.

Sambrook, J., Fritsch, E.F. and Maniatis, T.: Molecular Cloning. A Laboratory Manual, 2nd ed. Cold Spring Harbor Laboratory Press, Cold Spring Harbor, NY, 1989.

Sjöberg, B.-M., Hahne, S., Mathews, C.Z., Mathews, C.K., Rand, K.N. and Gait, M.J.: The bacteriophage T4 gene for the small subunit of ribonucleotide reductase contains an intron. EMBO J. 5 (1986) 2031-2036.

Tomich, P.K., Chiu, C.-S., Wovcha, M.G. and Greenberg, G.R.: Evidence for a complex regulating the in vivo activities of early enzymes induced by bacteriophage T4. J. Biol. Chem. 249 (1974) $7613-7622$.

Tseng, M.-J., Hilfinger, J.M., Walsh, A. and Greenberg, G.R.: Total sequence, flanking regions, and transcripts of bacteriophage T4 $\mathrm{nrd} A$ gene, coding for a chain of ribonucleoside diphosphate reductase J. Biol. Chem. 263 (1988) 16242-16251.

Tseng, M.-J., He, P. Hilfinger, J.M. and Greenberg, G.R.: Bacteriophage $\mathrm{T} 4 \operatorname{nrd} A$ and $n r d B$ genes, encoding ribonucleotide reductase, are expressed both separately and coordinately: characterization of the $n r d B$ promoter. J. Bacteriol. 172 (1990) 6323-6332.

Tseng, M.-J., He, P. Hilfinger, J.M. and Greenberg, G.R.: Cloning of bacteriophage $\mathrm{T} 4 \mathrm{nrd} A$ and $n r d B$ genes in a single plasmid and overproduction of ribonucleoside diphosphate reductase, $\alpha_{2} \beta_{2}$, and the mutationally altered enzyme, $\alpha_{2} \beta_{2}^{93}$. J. Bacteriol. 174 (1992) $5740-5744$.

Wirak, D.O.: Role of Bacteriophage T4 DNA-delay Gene Products in Deoxyribonucleotide Synthesis. Ph.D. Dissertation, The University of Michigan, Ann Arbor, MI, 1981.

Wirak, D.O. and Greenberg, G.R.: Role of bacteriophage T4 DNAdelay gene products in deoxyribonucleotide synthesis. J. Biol. Chem. 255 (1980) 1896-1904.

Wirak, D.O., Cook, K.S. and Greenberg, G.R.: Defect in synthesis of deoxyribonucleotides by a bacteriophage T4 $n r d B$ mutant is suppressed on mutation of T4 topoisomerase gene. J. Biol. Chem. 263 (1988) 6193-6201.

Yeh, Y.-C. and Tessman, I.: Control of pyrimidine biosynthesis by phage T4, II. In vitro complementation between ribonucleotide reductase mutants. Virology 47 (1972) 767-772.

Yeh, Y.-C., Dubovi, E.J. and Tessman, I.: Control of pyrimidine biosynthesis by phage T4: mutants unable to catalyze the reduction of cytidine diphosphate. Virology 37 (1969) 615-623.

Zimmern, D. and Kaesberg, P.: 3'-terminal nucleotide sequence of encephalomyocarditis virus RNA determined by reverse transcriptase and chain-terminating inhibitors. Proc. Natl. Acad. Sci. USA 75 (1978) 4257-4261. 